\title{
Large carnivore attacks on humans in central India: a case study from the Tadoba-Andhari Tiger Reserve
}

\author{
Harshawardhan S. Dhanwatey, Johnne C. Crawford, Leandro A. S. Abade \\ Poonam H. Dhanwatey, Clayton K. Nielsen and Claudio Sillero-Zubiri
}

\begin{abstract}
We examined human and ecological attributes of attacks by tigers Panthera tigris and leopards Panthera pardus on humans in and around the Tadoba-Andhari Tiger Reserve in the Chandrapur District of central India to provide recommendations to prevent or mitigate conflicts between people and large carnivores. During 2005-2011 132 carnivore attacks on humans occurred, 71 (54\%) of which were lethal to humans. Tigers and leopards were responsible for $78 \%$ and $22 \%$ of attacks, respectively. Significantly more victims were attacked while collecting minor forest products than during other activities. Probability of attack significantly decreased with increasing distance from forests and villages, and attacks occurred most frequently in the forested north-eastern corridor of the study area. Human activities near the Reserve need to be regulated and limited as much as possible to reduce human mortality and other conflicts. Increasing access to alternative fuel sources (e.g. biogas, solar) may reduce the pressure of timber harvesting on protected areas. Residents should be trained in identifying carnivore sign and in ways to reduce their vulnerability when working outdoors.
\end{abstract}

Keywords Human-carnivore conflict, human-dominated landscape, leopard, Panthera pardus, Panthera tigris, Tadoba-Andhari Tiger Reserve, tiger

\section{Introduction}

$\mathrm{H}$ uman-carnivore conflict is of special concern because of the potentially catastrophic consequences for both people and carnivores (Polisar et al., 2003; Nyhus \& Tilson, 2004; Patterson et al., 2004; Inskip \& Zimmermann, 2009) and because it is one of the major threats to the survival of large carnivores (Woodroffe et al., 2005). Among carnivores, large felids are particularly conflict-prone (Sillero-Zubiri \&

Harshawardhan S. Dhanwatey and Poonam H. Dhanwatey Tiger Research and Conservation Trust, Shivneri Ramdaspeth, Nagpur, India

Joanne C. Crawford (Corresponding author) and Clayton K. Nielsen Cooperative Wildlife Research Laboratory, Life Sciences II, Mail Code 6504 Southern Illinois University Carbondale, Carbondale, Illinois, USA. E-mail crawford.joanne@gmail.com

Leandro A. S. Abade and Claudio Sillero-Zubiri Wildlife Conservation Research Unit, University of Oxford, Oxford, UK

Received 12 August 2011. Revision requested 29 November 2011. Accepted 6 December 2011.
Laurenson, 2001; Karanth \& Gopal, 2005). The large habitat requirements and wide-ranging behaviour of these species frequently cause individuals to roam beyond protected areas, increasing their chance of becoming involved in conflict with humans and of being persecuted and killed (Karanth \& Gopal, 2005; Kolowski \& Holekamp, 2006; Loveridge et al., 2010).

Since the tiger Panthera tigris was first categorized as Endangered on the IUCN Red List (Chundawat et al., 2011), human populations within the tiger's range in Asia have doubled and people increasingly come into contact with tigers where resource use overlaps (Nyhus \& Tilson, 2010; Seidensticker, 2010). India is a human-tiger conflict hotspot in which an estimated 50\% of the global wild tiger population exists in only $11 \%$ of the globally available tiger habitat (Johnsingh et al., 2010; Seidensticker, 2010). Both tigers and leopards Panthera pardus prey on livestock and attack humans in India but in some areas of central India leopards are more often involved in conflict (Madhusudan, 2003; Athreya et al., 2004; Singh, 2005). Little is known, however, about either the ecology of carnivore attacks on humans in India or, more importantly, how to prevent such attacks effectively. As interactions between people and large carnivores increase in the periphery of many protected areas (Woodroffe \& Ginsberg, 1998), an understanding of the factors that influence carnivore attacks on humans is critical for effective conflict prevention.

Carnivore attacks on humans have increased sharply within the last two decades around the Tadoba-Andhari Tiger Reserve in the central state of Maharashtra, India. Since 2001 the Tiger Research and Conservation Trust has been working with government agencies in and around the reserve to facilitate relocation of settlements and mitigate human-carnivore conflicts (Crawford et al., 2011). Here, we use data collected during 2005-2011 to (1) summarize human characteristics associated with large felid attacks, (2) examine the influence of landscape factors on the probability of attack, and (3) suggest ways to prevent or mitigate carnivore attacks on humans in and around this and other tiger reserves.

\section{Study area}

The $6,045 \mathrm{~km}^{2}$ study area included the Tadoba-Andhari Tiger Reserve, commercial forests, and other State forests in the Chandrapur District in the Maharashtra state of central 


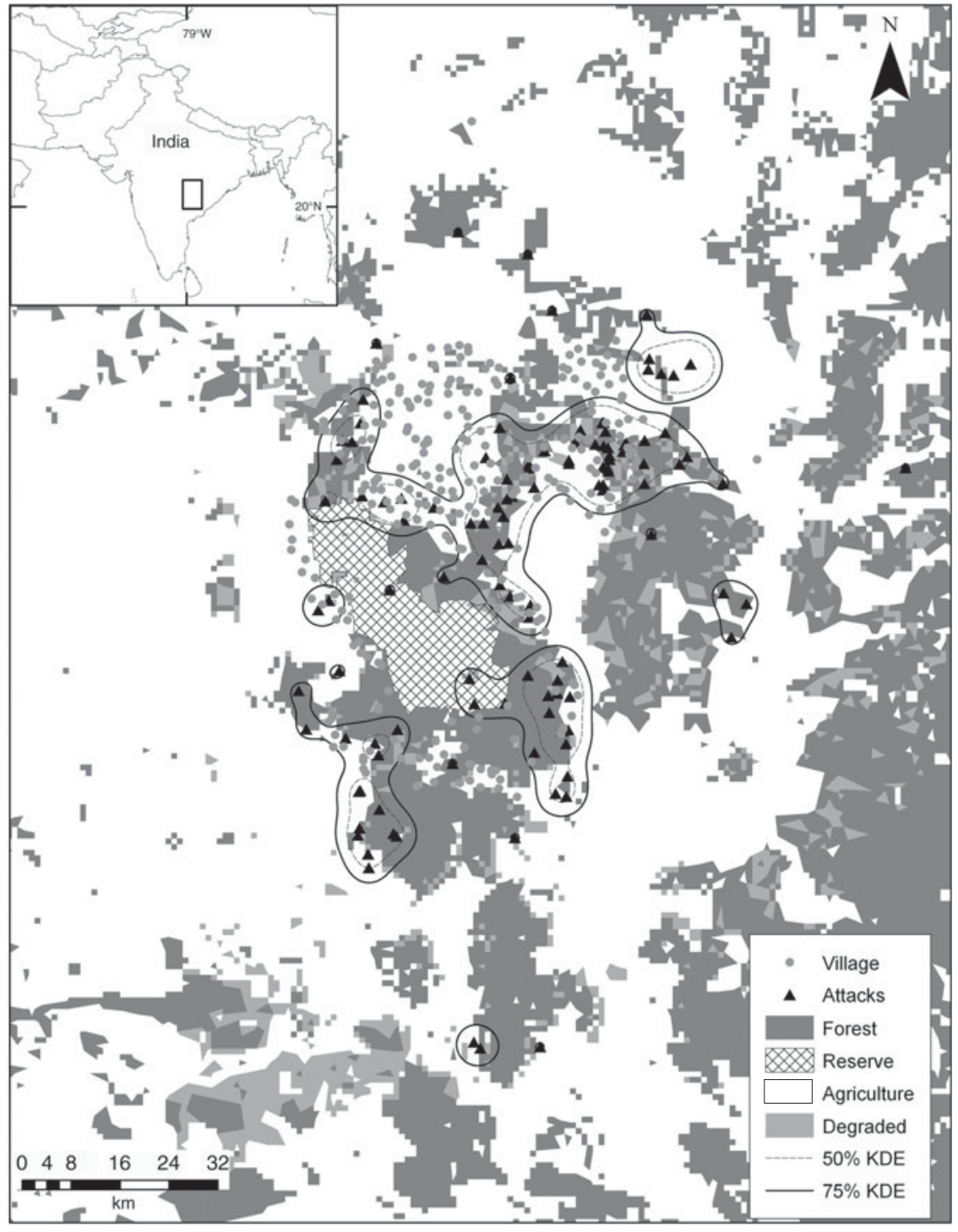

Fig. 1 The Tadoba-Andhari Tiger Reserve and surrounding buffer zone in Maharashtra State, central India. Kernel density estimators (KDE) of carnivore attacks on humans during 2005-2011 were used to delineate 75 and $50 \%$ isopleths of conflict. The $50 \%$ isopleths identify conflict hotspots, particularly along the north-eastern forested corridor.
India (Fig. 1). The forests are tropical dry deciduous and composed of teak Tectona grandis, Adina cordifolia, Anogeissus latifolia, Boswellia serrata, Diospyros melanoxylon, Madhuca indica and other species (Karanth \& Kumar, 2005). In 2001 the estimated density of tigers in the Reserve was 3.27 per $100 \mathrm{~km}^{2}$ (12 tigers; Karanth et al., 2004). The Reserve supports several other carnivore species, including leopard and dhole Cuon alpinus. Karanth et al. (2004) estimated combined prey density to be $13.1 \mathrm{~km}^{-2}$, with sambar Cervus unicolor, chital Axis axis, wild pig Sus scrofa and gaur Bos gaurus the most common prey species.

The buffer zone surrounding the Reserve contains 79 villages, with a total human population of c. 66,000 (Ministry of Home Affairs, Government of India, 2001). The buffer zone is composed of villages, tourist facilities and croplands. Cattle are grazed in buffer forests and firewood and fodder are harvested from forests near villages, leading to degradation in these areas (Nagendra et al., 2006).
Commercial and State forests beyond the buffer zone have land cover similar to that of the buffer and act as a corridor connecting the Reserve to the northern parks and tiger reserves of Maharashtra.

\section{Methods}

Human behaviour and activities

During 2005-2011 we visited the site of each carnivore attack within 3 days of the attack to record site variables and interview witnesses. Based on interviews with the victim or eyewitnesses we recorded the victim's gender, age, posture (standing or crouched) and activity at the time of the attack. We also asked eyewitnesses if the carnivore had been intentionally provoked or harassed. Activity was grouped into one of four categories: (1) cattle grazing, (2) minor forestproduct collection (firewood, tendu Diospyros melanoxylon, 
fodder), (3) mobbing or harassing the carnivore prior to the attack, or (4) other (travelling, or using a latrine). We grouped attacks into three seasons: summer (FebruaryMay), monsoon (June-September), or winter (OctoberJanuary). Differences in attacks between gender, activity and season were tested separately for tigers and leopards using $\chi^{2}$ tests $(\alpha=0.05$ throughout).

\section{Landscape characteristics of attacks}

We projected locations of attacks (in UTM coordinates; $\mathrm{n}=129$ ) in ArcGIS v. 9.3 (ESRI, Redlands, USA) for all spatial analyses. Fixed kernel density estimates (Worton, 1989) were used to identify zones with a high density of attacks, using Hawth's Tools (Beyer, 2004). We then used the nearest neighbour index in the Spatial Statistics extension to ArcView to test for significant spatial clustering relative to a random distribution, where values $<_{1}$ indicate spatial clustering and those $>1$ indicate a dispersed spatial pattern (Mitchell, 2005).

We reclassified land-cover types $\left(1 \mathrm{~km}^{2}\right.$ cell resolution) from the Global Land Cover 2000 Project (Roy et al., 2003) into three main cover types: forest, degraded forests, and agricultural areas. Degraded forests were categorized in the original land-cover file based on the analysis of Roy et al. (2003). We also projected UTM locations of 167 villages in the broader region and 79 villages within the buffer around the Reserve (Fig. 1). We visually confirmed cover types and village locations using Google Earth v. 6.1 (Google, Mountain View, USA). For each attack we measured the Euclidean distance to the Reserve boundary, and the nearest distance to forest (excluding the Reserve), degraded forest, agricultural field, and village. We examined differences in distance distributions between leopard and tiger attacks using KolmogorovSmirnov tests.

Multivariate logistic regressions were used to examine the importance of distance variables as predictors of the probability of attack. We generated 130 random (nonattack) points within the spatial extent of attack locations and measured the distance to each cover type for each point. We constructed generalized linear models with a binary response (attack/non-attack location) and logit-link function to assess the importance of each variable independently as a predictor using $\mathrm{AIC}_{\mathrm{c}}$ (Akaike information criterion) model selection (Burnham \& Anderson, 2002). The most important cover variable was then used as the first variable in a forward stepwise logistic regression, using a Wald statistic to determine model significance at each step, with the probability to enter the model at $\mathrm{P} \geq 0.05$. Model fit was assessed using a Hosmer \& Lemeshow (2000) goodness-offit test. All statistical tests were two-tailed and were calculated with SPSS v. 17 (SPSS Inc., Chicago, USA).

\section{Results}

\section{Human behaviour and activities}

We responded to 103 tiger and 29 leopard attacks on humans during 2005-2011, 71 (54\%) of which were lethal to humans. Tigers attacked more men than women $\left(\chi^{2}=15.86, \mathrm{df}=1\right.$, $\mathrm{P}<0.001)$ but more women died as a result of attacks $\left(\chi^{2}=13.62, \quad \mathrm{df}=1, \quad \mathrm{P}<0.001\right)$. Women were attacked primarily while harvesting minor forest products, particularly firewood, whereas men were attacked when grazing cattle or collecting minor forest products $\left(\chi^{2}=22.54, \mathrm{df}=4\right.$, $\mathrm{P}<0.001)$. Attacks did not vary by season $\left(\chi^{2}=1.82, \mathrm{df}=2\right.$, $\mathrm{P}=0.402$ ). Leopard attacks did not appear to differ by human gender, activity or season but sample sizes were too small to conduct $\chi^{2}$ tests. There was no evidence that either species selected targets or attacked based on age of the victim; the average age of victims was 42 (range 9-65). Of those people who died, half were dragged from the attack site but only $21 \%$ were partially consumed. Of 115 attacks for which we had eyewitness information, only 15 (13\%) resulted from the victim harassing the animal. Most people $(81 \%, \mathrm{n}=104)$ were in a crouched or sitting posture when attacked.

\section{Landscape characteristics of attacks}

Most attacks (96\%) occurred outside the Reserve, in the buffer zone (40\%) and surrounding landscape (56\%). Attacks were most numerous in forest (54\%), followed by agricultural lands (37\%) and degraded forest (9\%). Attacks were clustered along a north-eastern corridor that connects the Reserve, the buffer zone, and fragmented forests (Fig. 1; nearest neighbour index $=0.66, \mathrm{P}<0.001)$. Attacks were often within $5 \mathrm{~km}$ of villages and forest edges (Table 1). Distributions of distance to nearest patch for all cover types were not different between tiger and leopard attacks $(Z=0.74-0.94, \mathrm{P}=0.34-0.65)$.

Of the one-variable logistic models, the model that contained distance to village had the lowest $\mathrm{AIC}_{\mathrm{c}}$ value and, subsequently, this variable was the first variable to enter stepwise multivariate regression (Table 1). This variable and distance to forest were the only variables retained in the final model (Table 1). Probability of attack decreased with increasing distance from both forests and villages (Fig. 2). The Hosmer \& Lemeshow (2000) goodness-of-fit test indicated significant model fit for the final model $\left(\chi^{2}=12.13\right.$, $\mathrm{df}=8, \mathrm{P}=0.145)$. The model accurately classified $60 \%$ and $86 \%$ of random and attack locations respectively, giving a combined classification success of $73 \%$.

\section{Discussion}

Although attacks on people by tigers and leopards are relatively rare throughout much of the species' ranges, 
TABLE 1 Results of one-variable and final forward stepwise logistic regression used to model the probability of attack on humans by tigers and leopards around the Tadoba-Andhari Tiger Reserve (Fig. 1) during 2005-2011. All variables are nearest distances to the specified variable (land cover) from each location (attack/non-attack).

\begin{tabular}{|c|c|c|c|c|c|c|}
\hline Model & $\begin{array}{l}\text { Mean distance } \pm \\
\mathrm{SD}(\mathrm{km}) \text { to }^{1}\end{array}$ & $\beta$ (SE) & $\mathrm{AIC}_{\mathrm{c}}$ & $X^{2}$ & $\mathrm{P}$ & $\begin{array}{l}\text { Odds } \\
\text { ratio }\end{array}$ \\
\hline \multicolumn{7}{|l|}{ One-variable } \\
\hline Village & $5.0 \pm 7.4$ & $-0.09(0.02)$ & 305.12 & 34.33 & $<0.001$ & 0.91 \\
\hline Reserve & $23.4 \pm 15.6$ & $-0.03(0.01)$ & 338.04 & 23.33 & $<0.001$ & 0.97 \\
\hline Forest & $0.67 \pm 1.2$ & $-0.39(0.10)$ & 347.65 & 13.71 & $<0.001$ & 0.67 \\
\hline Degraded & $1.6 \pm 2.0$ & $-0.15(0.05)$ & 353.81 & 7.93 & 0.005 & 0.86 \\
\hline Agriculture & $0.72 \pm 1.0$ & $0.08(0.09)$ & 363.52 & 0.95 & 0.331 & 1.08 \\
\hline \multicolumn{7}{|l|}{ Final } \\
\hline Constant & & $1.18(0.21)$ & $294.62^{2}$ & 32.1 & $<0.001$ & 3.25 \\
\hline Village & & $-0.09(0.02)$ & & 32.1 & 0.001 & 0.92 \\
\hline Forest & & $-0.39(0.12)$ & & 10.4 & $<0.001$ & 0.68 \\
\hline
\end{tabular}

${ }^{1}$ Excluding attacks that occurred within the cover type

${ }^{2}$ Overall model $\mathrm{AIC}_{\mathrm{c}}$

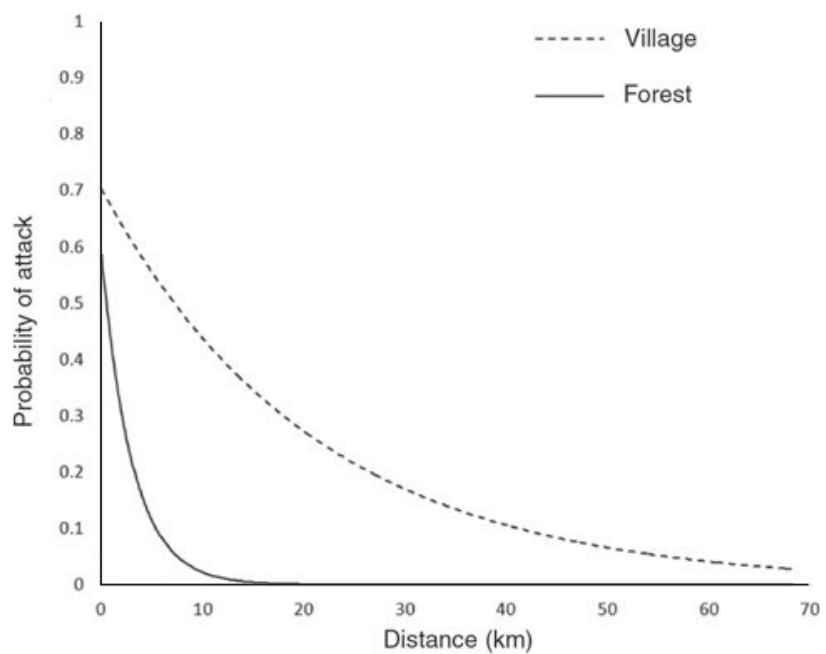

FIG. 2 Probability of attack on humans by large carnivores during 2005-2011 based on the distance to the nearest forest and village in the Tadoba-Andhari Tiger Reserve landscape.

conflicts remain high in South Asia (Singh, 2005; Barlow, 2009; Goodrich, 2010; Nyhus \& Tilson, 2010). Previous studies suggest that the vulnerability of people to attack by large carnivores is influenced not only by the biology of the carnivore, but also by poverty, gender, labour type and age of victims (Gurung et al., 2008; Ogra, 2008; Inskip \& Zimmermann, 2009). In our study area most victims were attacked by tigers or leopards when collecting forest products or grazing cattle in or near forests, and their outdoor activity increased both the likelihood of encountering wild carnivores and their vulnerability to attacks, which is comparable to reports elsewhere (Nyhus \& Tilson, 2004; Gurung et al., 2008).

Attacks by tigers were most numerous in forests and fields in the buffer zone and surrounding landscape, suggesting that some tigers are moving out of the Reserve.
In general, older males force younger tigers into peripheral low-quality habitats, such as those outside reserves and buffer zones, which have a shortage of prey and a ready availability of livestock (Nyhus \& Tilson, 2010). The wideranging behaviour of dispersing carnivores along with the low availability of wild prey in human-dominated landscapes increases the probability of tigers becoming involved in conflict (Goodrich, 2010; Nyhus \& Tilson, 2010).

In India leopards attack more humans than do other felids but predation on livestock by leopards is more common (Singh, 2005; Athreya et al., 2010) and (Madhusudan, 2003; Inskip \& Zimmermann, 2009). We expected attacks by leopards to occur closer to villages near large forests, and leopards were responsible for five of the seven attacks that occurred within $1 \mathrm{~km}$ of a village, but the spatial distribution of leopard attacks was nearly identical to that of tigers. Leopard attacks accounted for only 29 attacks in TadobaAndhari Tiger Reserve since 2005, which is consistent with findings by Athreya et al. (2010).

Human-carnivore conflicts tend to be more frequent near forest edges at the interface of human and carnivore activity, and in areas of high human density (Nyhus \& Tilson, 2004; Miquelle et al., 2005; Gurung et al., 2008; Nugraha \& Sugardjito, 2009). This also appears to be the case in the Tadoba-Andhari Tiger Reserve landscape, where both men and women are attacked primarily in the buffer of the Reserve or along the north-eastern corridor. Our regression model showed that, of the variables that we assessed, distance to village and distance to forest were the only important predictors of attack. Although the one-variable model containing distance to village was the top ranking model by $\mathrm{AIC}_{\mathrm{c}}$, distance to forest had a much greater influence $(\beta)$ on attack probability and most attacks occurred either in forest or $<5 \mathrm{~km}$ from a forest edge. The probability of attack decreased sharply with increasing distance to the 
nearest forest, approaching zero at $10 \mathrm{~km}$ from a forest (Fig. 2). However, such a strong relationship was not observed for the distance to a village, in which the probability of attack only gradually declined with increasing distance.

From these findings it would appear that villages on our study area were attack hotspots, but this was not necessarily the case. Most attacks occurred within or near forests that were proximal to villages. Villages in this area are typically located $<_{2} \mathrm{~km}$ from a forest edge, and the higher risk of attack is related to their proximity to tiger and leopard habitats. We also caution that, given the coarse resolution $\left(1 \mathrm{~km}^{2}\right)$ of our data, distances are estimates and demonstrate general trends in attack probability with distance to these cover types. Yet our coarse-grained approach still indicates that despite the tolerance of tigers and leopards to some level of disturbance and their ability to use human-dominated landscapes (Athreya et al., 2004; Goodrich, 2010) both carnivores appeared to be avoiding areas of heaviest human use in our study area. Large carnivores are attacking people primarily in 'edge' cover types, neither in the core of the Reserve nor in the heart of large urban areas.

Maharashtra is the second most populous state in India, and $60 \%$ of the human population around the TadobaAndhari Tiger Reserve primarily relies on natural resources for their livelihood (Ministry of Home Affairs, Government of India, 2001). The corridor to the north-east of the Reserve, where conflict is highest, has become highly fragmented and heavily used by humans (Nagendra et al., 2006). Illegal harvest of forest products and grazing of livestock near or in forests leave people particularly vulnerable to attack by carnivores. Greater effort needs to be made to limit illegal resource extraction and grazing. However, this is a significant challenge because most local people lack an alternative and often take a calculated risk when using areas frequented by large carnivores. Increasing access to alternative fuel sources (e.g. biogas, solar) would lessen reliance on forest products, reduce harvest pressure on forests and lower the likelihood of attacks on people by large felids.

The human-carnivore conflict in the Tadoba-Andhari Tiger Reserve and surrounding areas is influenced by a complex interaction of demographic aspects of the local communities, occupation, land use, and landscape features, as well as carnivore biology. Given the number of attacks on people, local communities need practical strategies to prevent such attacks. To reduce conflict here and in similar landscapes, we recommend (1) regulating and limiting human activities within reserve buffers, (2) training local residents to recognize carnivore sign and how to minimize their own risk, and (3) establishing rapid response teams, composed of qualified wildlife-capture personnel to be deployed to mitigate and prevent conflict from escalating in affected villages.

Currently the Tiger Research and Conservation Trust is training State Forest Department staff to monitor carnivore sign outside the Reserve (Crawford et al., 2011). Our map of high risk areas provides guidance to reserve managers and policy makers to define buffer size based on human activities and land use in the area, allowing them to identify in advance areas unsuitable for human use because of the potential for high conflict (Treves et al., 2004). The Trust also provides carnivore awareness training to village residents in which participants learn to recognize sign and strategies to reduce their vulnerability when working outdoors. For example, we recommend that people avoid working alone in forests, especially women and those harvesting firewood and other products that require crouching or bending over.

Lethal or serious attacks on people often lead to retaliatory or defensive killings, which may result in additional injuries to people and/or carnivores (SilleroZubiri et al., 2006). Personnel of the Tiger Research and Conservation Trust respond to reports of human-carnivore conflicts outside the Reserve to mitigate or prevent conflicts from escalating. This may involve relocating the carnivore involved in the conflict and, in some cases, results in the rescue and rehabilitation of orphaned cubs. We are currently working to establish a network of village residents trained to monitor carnivore sign in and around villages and report sightings to local officials or Trust personnel. Villages here represent the front line in human-carnivore conflicts. In the absence of a complete separation of people and large carnivore habitat, local preventative strategies and effective response to human-tiger conflicts will be key to the success of tiger reserves (Goodrich, 2010; Nyhus \& Tilson, 2010).

\section{Acknowledgements}

We are grateful to the Tadoba-Andhari Tiger Reserve field staff, R. Gopal (Member Secretary, National Tiger Conservation Authority) and B. Majumdar (former Chief Wildlife Warden, Maharashtra State Forest Department) for involving the Reserve in the conceptualizing of the Corridor Conservation Programme for the mitigation of Man-Tiger Conflict. The Tiger Research and Conservation Trust received funding support from the Born Free Foundation, Wildlife Conservation Trust, S. Dhanwatey and A. Naik. We appreciate comments from two anonymous reviewers that greatly improved the article. We also thank the Cooperative Wildlife Research Laboratory, Department of Forestry, Graduate School, and College of Agricultural Sciences at Southern Illinois University Carbondale, USA.

\section{References}

Athreya, V.A., Odden, M., Linnell, J.D.C. \& Karanth, K.U. (2010) Translocation as a tool for mitigating conflict with leopards in human-dominated landscapes of India. Conservation Biology, 25, $133^{-141 .}$ 
Athreya, V.R., Thakur, S.S., Chaudhuri, S. \& Belsare, A.V. (2004) A study of the man-leopard conflict in the Junnar Forest Division, Pune District, Maharashtra. Submitted to the Office of the Chief Wildlife Warden, Maharashtra State Forest Department, and the Wildlife Protection Society of India, New Delhi, India.

B ARLOW, A.C.D. (2009) The Sundarbans tiger: adaptation, population status and conflict management. $\mathrm{PhD}$ thesis. University of Minnesota, Saint Paul, USA.

Beyer, H.L. (2004) Hawth's Analysis Tools for ArcGIS. Http://www. spatialecology.com/htools [accessed 30 January 2013].

Burnham, K.P. \& D.R. Anderson. (2002) Model Selection and Inference: A Practical Information-theoretic Approach. Springer, New York, USA.

Chundawat, R.S., Habib, B., Karanth, U., Kawanishi, K., Ahmad Khan, J., Lynam, T. et al. (2011) Panthera tigris. In IUCN Red List of Threatened Species v. 2012.2. Http://www.iucnredlist.org [accessed 21 November 2012].

Crawford, J.C., Dhanwatey, H., Dhanwatey, P. \& Nielsen, C.K. (2011) Efforts by TRACT to conserve tigers in human-dominated landscapes of central India. Cat News 56, 20-22.

Goodrich, J.M. (2010) Human-tiger conflict: a review and call for comprehensive plans. Integrative Zoology, 5, 300-312.

Gurung, B., Smith, J.L.D., McDougal, C., Karki, J.B. \& BArLow, A. (2008) Factors associated with human-killing tigers in Chitwan National Park, Nepal. Biological Conservation, 141, 3069-3078.

Hosmer, D.W.J. \& Lemeshow, S. (2000) Applied Logistic Regression. John Wiley, New York, USA.

Inskip, C. \& Zimmermann, A. (2009) Human-felid conflict: a review of patterns and priorities worldwide. Oryx, 43, 18-34.

Johnsingh, A.J.T., Pandav, B. \& Madhusudan, M.D. (2010) Status and conservation of tigers in the Indian subcontinent. In Tigers of the World: The Science, Politics, and Conservation of Panthera tigris (eds R. Tilson \& P.J. Nyhus), pp. 163-173. Academic Press, Burlington, USA.

Karanth, K.U. \& Gopal, R. (2005) An ecology-based policy framework for human-tiger coexistence in India. In People and Wildife, Conflict or Coexistence? (eds R. Woodroffe, S. Thirgood \& A. Rabinowitz), pp. 373-387. Cambridge University Press, New York, USA.

Karanth, K.U. \& Kumar, N.S. (2005) Distribution and Dynamics of Tiger and Prey Populations in Maharashtra, India. Final Technical Report. Centre for Wildlife Studies, Bangalore, India.

Karanth, K.U., Nichols, J.D., Kumar, N.S., Link, W.A. \& Hines, J.E. (2004) Tigers and their prey: predicting carnivore densities from prey abundance. Proceedings of the National Academy of Sciences of the United States of America, 101, 4854-4858.

Kolowski, J.M. \& Holekamp, K.E. (2006) Spatial, temporal, and physical characteristics of livestock depredations by large carnivores along a Kenyan reserve border. Biological Conservation, $128,529-541$.

Loveridge, A.J., Hemson, G., Davidson, Z. \& Macdonald, D. (2010) African lions on the edge: reserve boundaries as "attractive sinks". In Biology and Conservation of Wild Felids (eds D. W. Macdonald \& A.J. Loveridge), pp. 283-304. Oxford University Press, New York, USA.

Madhusudan, M.D. (2003) Living amidst large wildlife: livestock and crop depredation by large mammals in the interior villages of Bhadra tiger reserve, South India. Environmental Management, 31, $466-475$.

Ministry of Home Affairs (2001) Census Report, Government of India. Http://www.censusindia.gov.in/Census_Data_2001/ India_at_glance/density.aspx [Accessed 14 July 2011].
Miquelle, D.G., Nikolaev, I., Goodrich, J.M., Litvinov, B., Smirnov, E.N. \& Suvorov, E. (2005) People and tigers in the Russian Far East: searching for the 'coexistence recipe'. In People and Wildlife, Conflict or Coexistence? (eds R. Woodroffe, S. Thirgood \& A. Rabinowitz), pp. 305-322. Cambridge University Press, New York, USA.

Mitchell, A. (2005) The ESRI Guide to GIS Analysis: Spatial Measurement and Statistics, vol. 2. ESRI Press, Redlands, USA

Nagendra, H., Pareeth, S. \& Ghate, R. (2006) People within parks-forest villages, land-cover change and landscape fragmentation in the Tadoba Andhari Tiger Reserve, India. Applied Geography, 26, 96-112.

Nugraha, R.T. \& Sugarditio, J. (2009) Assessment and management options of human-tiger conflicts in Kerinci Seblat National Park, Sumatra, Indonesia. Mammal Study, 34, 141-154.

Nyhus, P.J. \& Tilson, R. (2004) Characterizing human-tiger conflict in Sumatra, Indonesia: implications for conservation. Oryx, $38,68-74$.

Nyhus, P.J. \& Tilson, R. (2010) Panthera tigris v. Homo sapiens: conflict, coexistence, or extinction? In Tigers of the World: The Science, Politics, and Conservation of Panthera tigris (eds R. Tilson \& P.J. Nyhus), pp. 125-142. Academic Press, Burlington, USA.

OGRA, M.V. (2008) Human-wildlife conflict and gender in protected area borderlands: a case study of costs, perceptions, and vulnerabilities from Uttarakhand (Uttaranchal), India. Geoforum, $39,1408-1422$.

Patterson, B.D., Kasiki, S.M., Selempo, E. \& Kays, R.W. (2004) Livestock predation by lions (Panthera leo) and other carnivores on ranches neighboring Tsavo National Parks, Kenya. Biological Conservation, 119, 507-516.

Polisar, J., Maxit, I., Scognamillo, D., Farrell, L., Sunquist, M.E. \& EisenberG, J.F. (2003) Jaguars, pumas, their prey base, and cattle ranching: ecological interpretations of a management problem. Biological Conservation, 109, 297-310.

Roy, P.S., Agrawal, S., Joshi, P. \& Shukla, Y. (2003) The Land Cover Map for Southern Asia for the Year 2000, GLC200o Database, European Commission Joint Research Centre. Http://bioval.jrc.ec. europa.eu/products/glc200o/glc2000.php [accessed 30 January 2013].

Seidensticker, J. (2010) Saving wild tigers: a case study in biodiversity and challenges to be met for recovery beyond 2010. Integrative Zoology, 5, 285-299.

Sillero-Zubiri, C. \& Laurenson, M.K. (2001) Interactions between carnivores and local communities: conflict or co-existence? In Carnivore Conservation (eds J. Gittleman, S. Funk, D.W. Macdonald \& R.K. Wayne), pp. 282-312. Zoological Society of London, London, UK.

Sillero-Zubiri, C., Sukamar, \& Treves, A. (2006) Living with wildlife: the roots of conflict and the solutions. In Key Topics in Conservation Biology (eds D.W. Macdonald \& K. Service), pp. 253-270. Blackwell Publishing, Oxford, UK.

Singh, H.S. (2005) Status of the leopard Panthera pardus fusca in India. Indian Forester, 131, 1353-1362.

Treves, A., Naughton-Treves, L., Harper, E.K., Mladenoff, D. J., Rose, R.A., Sickley, T.A. \& Wydeven, A.P. (2004) Predicting human-carnivore conflict: a spatial model derived from 25 years of data on wolf predation on livestock. Conservation Biology, 18, 114-125.

Woodroffe, R. \& Ginsberg, J.R. (1998) Edge effects and the extinction of populations inside protected areas. Science, 280, 2126-2128.

Woodroffe, R., Thirgood, S. \& Rabinowitz, A. (2005) The impact of human-wildlife conflict on natural systems. In People and Wildlife, Conflict or Coexistence? (eds R. Woodroffe, S. Thirgood \& 
A. Rabinowitz), pp. 1-12. Cambridge University Press, New York, USA.

Worton, B.J. (1989) Kernel methods for estimating the utilization distribution in home-range studies. Ecology, 70, 164-168.

\section{Biographical sketches}

Harshawardhan Dhanwatey and Poonam Dhanwatey are co-founders and trustees of the Tiger Research and Conservation Trust in Nagpur, India, and recipients of the 2004 Carl Zeiss Roll of Honour for their conservation efforts. JOANNE CRAWFORD is interested in spatial and wildlife ecology, with an emphasis on mammalian conservation. LEANDRO ABADE is interested in human-carnivore conflict, spatial modelling and carnivore species distribution. Clayton Nielsen is an applied wildlife ecologist and a member of the IUCN Cat Specialist Group. Claudio Sillero-Zubiri works on carnivore conservation and human-wildlife conflict and is the Chair of the IUCN Canid Specialist Group. 